\title{
The Profile of Effective EFL Teachers: A Descriptive Study at Senior High Schools in Gowa
}

\author{
Dian Wahyu Restu \\ dianwahyurestu1990@gmail.com \\ Haryanto Atmowardoyo \\ haryanto@unm.ac.id \\ Mansur Akil \\ mansurakil@unm.ac.id \\ English Education Department of Graduate Program \\ State University of Makassar, Indonesia
}

\begin{abstract}
This research aimed at to find out the profile of effective EFL teachers based on four competences as stated in Permendiknas number 122007 at senior high school level; pedagogical competence, personal competence, social competence, and professional competence. This research employed descriptive qualitative research method. This research was conducted in SMAN 2 Tinggimoncong, SMAN 1Bajeng, and SMAN 1 Sungguminasa which were the three of the best and the most favorite state schools in Gowa Regency. The research subjects were EFL teachers. Before selecting the research subjects, a questionnaire with open responses was given to the all the third grade students in each school in order to find out their perceptions and opinions about their English teachers. Then, an English teacher who was mostly chosen by student was selected from each school as a research subject. Additionally, the second questionnaire was distributed to third graders to 10 students from each school to showed that two of three teachers classified as effective teachers in four competences.
\end{abstract}

Keywords: Effective EFL teacher, pedagogical competence, personal competence, social competence, professional competence

\section{INTRODUCTION}

English language teachers play a fundamental role in teaching and learning process. Their capability in teaching the subject and transferring their knowledge determines the success or failure of students in their academic achievement. The ability of teachers means that teachers are able to maintain relationship with students in a wide variety of activities, classroom management, organization, understanding learning styles, providing engaging activities, and much more. Then, all of these teachers' abilities and qualifications come together to create a fun and effective learning in the classroom.

In Indonesia, there are some qualifications that must be fulfilled by a teacher. Based on The Minister Regulation of National Education (PeraturanMenteriPendidikan Nasional Republik Indonesia/ Permendiknas) Number 16 (2007), teachers are required to have an academic qualification, competence, teaching certificate, good condition and mental, and ability to achieve national education goals. And also based on Permendiknas Number 12 
(2007) through professional education, they also need to fulfill the teacher competences. They are pedagogical, personal, social, and professional competence.

Teachers' competences might be used to be effective English teachers in classroom setting. A term like effective English language teachers or good English teachers is a kind of popular topics that has become one of the major attentions by many researchers by using students' perception. People believe that the level of the teacher's effectiveness in teaching a subject will give positive effect to the students' improvement in learning the subject. The effective English Foreign Language (EFL) teachers have different characteristics with those ordinary ones.

Due to the significance of effective EFL teachers, it is important to investigate the profile of effective English language teachers and their daily interaction of teaching activities in real classroom circumstances.

\section{RELATED LITERATURE}

\section{The Concept of Teaching Effectiveness}

a. Definition of teaching effectiveness

There are some definitions of teaching effectiveness according to some experts; James (2013:6) said that effective teaching is something that must be done in relation to understanding the objectives of education. Promoting students' cognitive development can be seen as one of the prime purposes of education and teaching, though there are also likely to be other important social, behavioral and affective current and future oriented purposes and goal of education. It is also related to Barbara (2009:5) states that teacher effectiveness is meant to be the collection of teachers' characteristics, competencies, and behaviors at all educational levels that enable students to reach desired outcomes, which may include the attainment of the specific learning objectives as well as broader goals such as being able to solve problems, think critically, work collaboratively, and become effective citizens.

The qualities of effective teaching cannot be separated from qualities of effective teacher and effective teaching in an appropriate learning environment. Gurney (2007:91-96) suggest the following five key factors that provide a foundation for a good teaching:

1. Teacher knowledge, enthusiasm and responsibility for learning.

2. Classroom activities that encourage learning.

3. Assessment activities that encourage learning through experience

4. Effective feedback that establishes the learning processes in the classroom.

5. Effective interaction between teacher and the students, creating an environment that respects, encourages and stimulates leaning through experience. 
Teaching effectiveness is related to the way of teacher in teaching, managing, and delivering materials to lead her/his students to gain the school objectives in the classroom and also to inspire their students, to affect the students' emotion in social, affective and behavior outside of the classroom.

\section{b. Effective language teaching}

In order to have an effective language classroom the teacher should know some stages in conducting the teaching and learning process. Richards \& Bohlke (2011:9) state that a language lesson consists of a sequence of activities that lead toward your lesson goals or objectives. On their book, Richards and Bohlke emphasize to the three essential stages of a lesson: opening, sequencing, and closing.

\section{Characteristics of Effective English Foreign Language}

The characteristics of effective teacher may vary according to several experts. Stronge, Tucker, \& Hindmanl (2004:9-16) explain prerequisites of effective teaching that linked to effective teachers, they are:

\section{a. Verbal Ability}

Effective teachers know their students and how to communicate with the, both individually and collectively. Some students prefer "just the facts" while others want to hear a narrative, and then there are others with completely different learning styles and communication needs. Effective teachers carefully consider their audience when delivering a massage. They observe reactions and decide how best to get their point across to different individuals. From the explanation of Stronge, et.al above, it can be concluded that an effective teacher should know how to react with the circumstance surrounding him/her.

\section{b. Content Knowledge}

The teacher is an educator for the students. Therefore, the teacher should know the material or the subject that is being taught by them. The major understanding of the teacher through their subject will help them to manage the classroom in a better way.

\section{c. Educational Coursework}

The courses teachers took as part of their preparation program for teaching or as a part of postgraduate work to earn their teacher certification, but educational coursework does not stop with the signing of a teaching contract. Teachers must continue to develop their professional knowledge in order to renew their licenses and, perhaps more importantly, to renew themselves.

\section{d. Teacher Certification}

Teacher certification is determined by individual states and is issued to individuals whom the states deems qualified to teach based on criteria. 
Additionally, teacher certification enhances effectiveness so long as teacher are assigned to teach in their field of preparation.

\section{e. Teaching Experience}

Emphasizing on teaching experience, there is no such limitation about how many years the teachers can be categorized as an experienced teacher. Every teacher has different kinds of experience.

The level of teachers' experience which use by them is decided by the teacher herself. Whether they want to use their experience and formulate new kinds of teaching method in their classroom depends on their selves.

Furthermore, Stronge (2007:100) states that the qualities of effective teachers might be summarized fewer than four overarching statements which describe the effective teacher for students of all ability levels and backgrounds:

1. The effective teacher care deeply

2. The effective teacher recognizes complexity.

3. The effective teacher communicates clearly.

4. The effective teacher serves conscientiously.

Walls, Nardi, Von Minden, \& Hoffman (2002), examine the characteristics of effective and ineffective teachers by focusing on the perceptions of prospective, novice, and experienced teachers. This study has raised five dimensions which cover the terms of effective and ineffective teachers. The five dimensions are:

1. Emotional environment

2. Teacher

3. Teacher motivation

4. Student participation

5. Rules and grade

This research emphasizes the character of effective English language teachers as the teacher that could have master the four competences (pedagogical, personal, social, and professional) and quality based on the Minister Reguation of National Education (Peraturan Menteri Pendidikan Nasional Republik Indonesia) number 12 (2007) had arranged standard academic qualification and competence of teachers. Those criteria of teachers' competence standard stated on Permendiknas number $12 / 2007$.

\section{RESEARCH METHOD}

This study applied a descriptive qualitative method to describe and analyze the profile of effective EFL teachers from SMAN 2 Tinggimoncong, SMAN 1 Bajeng, and SMAN 1 Sungguminasa, the three best and the most favorite state schools in Gowa regency, South Sulawesi. The data were taken using open-ended questions a questionnaire taken from an assessment instrument for Indonesian EFL teachers 'performance based on students' perceptions developed by Atmowardoyo et al (2017), included as an appendix. .

The research subjects in this study were English teachers in Gowa regency. Before selecting the research subjects, the researcher gave a questionnaire with open responses to 
the all of $3^{\text {rd }}$ grades students in order to find out their perceptions and opinions about their English teachers. The reason of choosing student of grade XII was the students had been taught more than one English teacher in their school and they could compare who were the English teacher they liked.

Based on the questionnaire with open responses, the researcher concluded that one English teacher, mostly chosen by the students. After getting the first questionnaire results, the researcher distributed second questionnaire to third graders to 10 students to find out whether the English teacher was effective or not. The results of the second questionnaire showed the results of effective or highly effective teachers, then the researcher conducted interviews with the selected teachers. At last, the most important one, the researcher confirmed the selected subjects' agreement to be the research subjects of this research in order to gain a valid data about the subjects.

\section{FINDINGS AND DISCUSSION}

Questionnaire 1 is preliminary question for choosing favorite English teacher. After obtaining the result, the researcher found that there was three English teacher from three schools. Questionnaire 2 was given to find out if the teacher selected was an effective teacher. The results of questionnaire 2 on three teachers from three schools showed that only two teachers were included in the category of effective English teachers. The first subject get range 76-85 score is categorized very effective teacher. The second subject get range 74- 86 score is categorized very effective teacher. The third subject get range 42-52 score is categorized ineffective teacher. Because this study focuses on the effectiveness of EFL teachers' profiles, two proven effective subject teachers have been interviewed. In the further interpretation of data analysis were given below.

\section{The Characteristics of Effective EFL Teachers in Pedagogical Competences.}

The researcher found out four characteristics from the two subjects as a profile effective teacher in area pedagogical competence. Those are:

a. The teacher should understand the students' characteristics.

The first aspect must be the effective English teacher needs. Students' characteristics are dealing with students' difficulties, students' condition, students' ability, and students' personality. For an effective English teacher must know learners who have successfully mastered certain lesson materials and who have not mastered, then in this case the teacher can focus on students who have not mastered the lesson, and find the cause and then give a thorough behavior so that its success can be further improved. The teachers also need to know the students' condition to make good classroom circumstances. Lastly, the teachers must to know the students' ability and student personality to treat them in different ways.

\section{b. Have good capability in delivering material}

Shisavan \& Sadghi (2009:132) state that there is a need having the ability in choosing appropriate teaching strategies and ability to organize earning activities on the development of standard in foreign language teacher preparation. The student mentioned 
they liked their teacher because language his used is easy to understand, explained the material clearly, applying various method, interesting, more practice and giving motivation. Language easy to understand means the teacher used a word in his utterance is familiar in students or the teacher translate in Indonesia what the meaning. Not at all students having a high vocabulary mastery. Therefore, in teaching and learning process, it does not recommend to use English only because some students did not understand. The teacher also always new word so the students know many vocabularies.

In explaining material clearly, their effective EFL teachers demonstrate good pronunciation. One of the effective teachers has a high volume voice but various intonations. Another effective EFL teacher also uses various intonations. Celik, et al (2013) said that the profile of effective foreign language teachers can be established as one who teaches pronunciation well, has a sound knowledge of vocabulary, adapts explanations in the mother tongue. When the teachers' pronunciation is wrong, students also would be wrong so the teacher should use correct pronunciation.

In delivering material, most students like if their teacher use jokes or humor and games. Games make the material taught be challenging so the student passionately learn English. Harmer (1998: 1-3) said that some qualities which good teachers possess is an ability to give interesting classes games make students more interested in learning English.

The students liked English subject because their teacher apply more practice than theory. Both of the effective English teacher more focused in speaking skill but not forget to correct their student grammar. But the first they do is motivate their students to practice English or implant to their student soul is English your needed. Motive learners is one of teacher should have. Kalebic (2005 in Shishavan \& Sadeghi, 2009:132) who said teachers required for having the ability to motivate learners for learning.

\section{c. Developing curriculum}

In developing curriculum to be material taught, the effective English teachers should be observed the material that is suitable to student ability. The material should be suitable with aim listed educational curriculum and easy to understand. To make good class circumstances, the material taught should be easy to understand. It means the concept for delivering material is should be simple and systematic. The teachers arranged the learning material based on appropriate approach and students' need.

\section{d. Using ICT}

The effective teacher not only supports learning from textbooks. They are use technology and make authentic material in their learning. Information and technology are usually used by the teachers such as computer and LCD to help them explaining the material by PowerPoint presentation. To attract the interest students, the teachers use video, song, english movie and drama. The video is one of way to improve the student speaking skill and writing skill. After the students watch the video, the teacher will asks them to repeat 
what happen in the video and write their opinion or review or complete the ending story based on the students' imagination. Song used to improve the students listening.

\section{The Characteristics of Effective EFL Teachers in Personal Competences.}

The personal competence the effective EFL teachers have such as kind, humorous, patient, cheerful and easy smile, wise, and discipline.

\section{a. Kind}

Teacher should be a kind person. The effective teachers should have that characteristic. They always have positive thinking to their students even though the students have negative attitudes. They always positive think to their student and care of the way they treat their students. They never judge their student or labeling student with stupid student or inferior the students even though the student gets low achievement. But they think how to good way to make the students understand. They care about the students. It is related the characteristics of effective stated Walls (2002) who said effective teachers have warm, friendly, and caring category.

\section{b. Humorous}

Humorous teacher is mostly like characteristic from effective EFL teachers. The humorous teacher can create an enjoy and good classroom atmosphere. The class situation and condition are also some aspect that important to see on teaching and learning process inside the classroom. That is why an effective EF teacher should create a good classroom circumstance. Using humor in the classroom is one way that can increase students' willingness in studying as well as increase their participation in the classroom. Indirectly, humorous teacher can build up close relationship with students and help them in studying.

\section{c. Patient}

Both of the effective teachers are patient person. All their students said their teacher never angry. It is same line with the teachers' statement. One of effective teacher said that sometimes angry but he just speaks friendly to his students about what the students' problems. The teachers also must be patient in explaining material to the students.

\section{d. Cheerful and easy smiles}

The effective teacher is cheerful and easy smiles. The students do not feel awkward if their teacher is cheerful and easy smiles. When students do not feel awkward with his teacher is can make communicative effective.

e. Wise

The teacher should be wise to the students. The teacher should wise when face the negative attitude student and also when his face a problem. When teachers entering the classroom, their face must be happy like acting like not face problems. 


\section{f. Discipline}

In this case, discipline teacher refers to a teacher discipline time, appearance, attendance and submitting assignment. Discipline time is the EFL teacher who began and ended the class on time. Those who know how to spent time in the class effectively. Teacher as a model in context of all activity which take place in the classroom is demanded to have good time management. It includes how the class is began and ended effectively and efficiently with sufficient time. Discipline appearance is the teacher must be look as a teacher. Teacher is a role model for students. Look as teacher means the teacher must well dressed, natty, and presentable. Discipline attendance is the teacher should come to class for teaching. Because there are some teachers are come to class just give assignment to his student and go away. Discipline submitting assignment is the teacher submit the student assignment and give back to student after he check and give correction to students' assignment. All the discipline is looked simply but has great impact on students when it is used wisely but it is also may have negative influence when it is used ineffectively.

\section{The Characteristics of effective EFL teacher in Social Competence}

This section deals the profile effective EFL teacher in area social competence, they are:

\section{a. Being objective}

The effective EFL teacher treat their students objectively and not discriminative. They conscious every student has a different ability such as high, medium, and low achievement. They not only pay attention to the smart students. They pay more attention to the students who has low ability. They create different treat to make all the student understand what he teaches in class. So, the low students also can get what he means. When they teach English usually combines the language, Indonesia and English. Mostly they use English. They know where is class he teaches is most of slow think in English so they create different treatment or method in his teaching.

\section{b. Communicative effectively}

Because limited time in class or school to make communicate effective between teacher and student, so to make communicative effectively, one of the effective teacher use social media such as WhatsApp and BBM. Most of the students were really happy when they know their teachers have a social media account. Social media become one of the tools to provide the communication. Students did not feel awkward and feel free to ask about assignment they do not understand. The other effective teacher, in his school forbidden their students brings handphone. However, the teacher can make communicative effective with his students because the school is boarding school and students can meet their teacher anytime. It is in line with Stronge, et. al (2004) who said that is one of the characteristics of effective EFL teacher. 


\section{c. Able to interact}

The effective EFL teachers have good relationship between students and other teachers. It means they are able to interact with others. Being able to interact well with students can established harmonious relationship with students and other teachers. Harmonious relationship with student will bring a positive impact in learning. The student will more participate in learning. It can make teaching more effective.

\section{d. Develop communication}

Develop communication means that the effective EFL teachers build communication with students. They always have time to their students. They want to know students' difficulty in learning and build a close relationship. Because limited time in school, one of effective EFL teacher use social media but it doesn't mean the students cannot meet him in school or after teaching for sharing. And other effective teacher build communication with permit his students meet him in school or come to his house. Because in his school forbidden the students brings handphone. They always think how to build communication.

\section{The Characteristics of effective EFL teacher in Professional Competence}

This section deals the characteristics of effective EFL teacher in professional competence.

\section{a. Mastering of the material of subject taught}

The effective English teacher have to mastering of the material of subject taught. Before they teach in classroom, they prepared. One of effective teacher is prepare such as lesson plan, material of teaching and class management. Moreover, the effective EFL teachers have form or mindset in their what they want apply in the class. They become experts in sharing their material with their students in meaningful ways. All the effective EFL teachers has been more than 10 years teaching English. Even though there is no such limitation about how many years the teachers can be categorized as an experienced teacher, but their experience can improve their teaching in the classroom. Classroom experiences provide insight for teachers to understand the character of students and how to deal with such diversity. The teacher knows what the best method for what subject, because he has tried many times. They also always improve their skill in teaching with various ways.

\section{b. Creative learning material}

The effective EFL teachers do not support their teaching from textbook. They think and apply suitable material for their level student. They also select teaching and learning material is material can attract interest their student in learning English. 
c. Academic qualification related with the teacher teaching.

The effective EFL teacher should have academic qualification related with the teacher teaching. One of effective teacher is a bachelor degree (S1) and other effective teacher is graduated (S2). It is appropriate with the academic qualification for senior high school teachers or equivalent must have a minimum education qualification of Diploma (D-IV) or bachelor degree (S1) study program related to the subjects that are taught and was obtained from accredited institution.

d. Have interest to be a teacher.

The effective EFL teachers have the dream of becoming a teacher since the time in school. The one of effective teacher is inspired by his English teacher while at school. It is also supported because his brothers are teachers. Other effective teachers since the childhood bench aspire to become a teacher. It is also strengthened by the urge to be better than the parents. It is appropriate Article 7 paragraph (1) of the Law of the Republic of Indonesia number 14 of 2005 with one of principle of teacher profession or lecturer profession have talent, interest, calling soul, and idealism.

\section{CONCLUSION AND SUGGESTION}

The research concluded that is difficult to be effective EF teacher. That is appropriate with the fact that the researcher find from 3 school, there is one school is does not have an effective EFL teacher. Even though the teacher chooses as favorite English teacher that other English teachers in their school. All the effective EFL teachers have a four competence. All these competencies are interlinked and supportive of each other. An effective teacher cannot be said to be an effective teacher if he or she has only three competencies.

The findings of this study suggested the teachers to improve themselves independently in order to fulfill standard competences as effective teachers and the government (Educational Department) to conduct training for developing teachers' competence, especially professional and personal competence.

\section{REFERENCES}

Atmowardoyo. H. (2008). Metode Penelitian Kualitatif: Teori Dasar. Makassar: Badan Penerbit Universitas Negeri Makassar. . (2010). Research Methods for Language and Literature Studies. Makassar: Badan Penerbit Universitas Negeri Makassar.

Atmowardoyo, H., Ja'faruddin, J., Khaerati, K., (2017). Developing an Assesment Instrument for Indonesian EFL Teachers' Performance Based on The Students' Perceptions. International Journal of Science and Research 
Vol 6 No 7, pp. 608-614, Retrieved from www.ijsr.net DOI: 10.21275/ART20175363

Celik, S. (2013). In the eyes of Turkish EFL learners: What makes an effective foreign language teacher? Porta Linguarum, 20,287-297. Retrieved from

http://www.ugr.es/ portalin/articulos/PL_numero20/18\%20Servet\%20C elik.pdf

Gay, L. R. \& Mills, G.E. and Airasian, P. (2006). Educational Research. Competencies for Analysis and Application. Singapore: Pearson Merril Prentice Ltd.

Gurney, P. (2007). Five Factors for Effective Teaching New Edition. New York: Longman.

Harmer, J. (1998). The Practice of English Language Teaching. New York: Longman

Shishavan, H.B \& Sadeghi, K. (2009). Characteristics of an Effective Language Teacher as Perceived by Iranian Teachers and Learners of English. CCSE

(http://www.csnet.org/journal/index.php/elt/article/viewFile/4462/3803, Accessed on January 2st 2017)

Stronge, J.H. (2007a). Qualities of Effective Teachers Second Edition. Alexandria: ASCD . (2007b). Kompetensi Guru-Guru Efektif Edisi Kedua. Translation by Tjo, E. Jakarta: Indeks.

Stronge, J.H., Tucker, P.D \& Hindman, J.L. (2004). Handbook for Qualities of Effective Teachers. Alexandria:ASCD.

Undang-undang Republik Indonesia Nomor 16 Tahun 2005 tentang Guru dan Dosen. Departemen Pendidikan Nasional.

Undang-undang Republik Indonesia Nomor 14 Tahun 2005 tentang Guru dan Dosen Departemen Pendidikan Nasional

Undang-undang Indonesia Nomor 12 Tahun 2007 tentang Standar Nasional Pendidikan.

Walls, R., Nardi, A., Von Minden, A., \& Hoffman, N. (2002). The Characteristics of Effective and Ineffective Teachers Education. Quertly, 29, p. 39-48) 


\title{
ASSESSMENT INSTRUMENT OF INDONESIAN EFL TEACHERS' PERFORMANCE BASED ON STUDENT'S PERCEPTION
}

\author{
Developed by: Haryanto Atmowardoyo, Ja'faruddin, and Khaerati
}

Name of Teacher:

Directions: (Petunjuk:)

Dear students, please recall the way how your English teacher teaches you. Give the scores for him/her by reading the following 44 statements and circle the score under every statement for him/her based on your perception. Score 1 means "strongly disagree"; score 2 means "disagree"; score 3 means "agree", or score 4 means "strongly agree".

(Siswa yang terhormat, cobalah ingat-ingat bagaimana guru bahasa Inggris Anda mengajar Anda. Beri nilai untuk dia dengan membaca 44 pernyataan berikut dan melingkari skor di bawah setiap pernyataan untuknya berdasarkan persepsi Anda. Skor 1 berarti "sangat tidak setuju"; Skor 2 berarti "tidak setuju"; Skor 3 berarti "setuju", atau skor 4 berarti "sangat setuju".)

1. The teacher uses English well and fluently, writes correctly, and masters the English grammar well. (Guru menggunakan bahasa Inggris dengan baik dan lancar, menulis dengan benar, serta menguasai tata bahasa Inggris dengan baik.)

$$
\begin{array}{llll}
1 & 2 & 3 & 4
\end{array}
$$

2. The teacher performs innovative and varied learning. (Guru melakukan pembelajaran yang inovatif dan variatif.)

$$
\begin{array}{llll}
1 & 2 & 3 & 4
\end{array}
$$

3. The teacher uses clear learning steps. (Guru menggunakan langkah-langkah pembelajaran yang jelas.)

$$
\begin{array}{llll}
1 & 2 & 3 & 4
\end{array}
$$

4. The teacher knows the student's learning needs and knows how to recognize the student's abilities. (Guru mengetahui kebutuhan belajar siswa dan mengetahui cara mengenali kemampuan siswa.)
1
2
3
4

5. The teacher delivers the material clearly, simply, and systematically. (Guru menyampaikan materi secara jelas dan sederhana dan sistematis.) 
6. The teacher provides speaking and writing exercises in English. (Guru memberikan latihan berbicara dan menulis dalam bahasa Inggris.)

$\begin{array}{llll}1 & 2 & 3 & 4\end{array}$

7. The teacher's way of teaching is accompanied by ice breakers and jokes. (Guru mengajar yang disertai dengan ice breaker dan lelucon.)
1
2
3
4

8. The teacher always motivates students in every lesson to be always enthusiastic, including encouraging students to be able to memorize new words and use them in conversation. (Guru selalu memotivasi siswa dalam setiap pembelajaran untuk selalu antusias, termasuk mendorong siswa untuk dapat menghapal kata-kata baru dan menggunakannya dalam percakapan.)
1 2 3 4

9. The teacher is cheerful and easily smiles. (Guru bersikap riang dan murah senyum.)
1
2
3
4

10. The teacher uses electronic media in the form of movies or song in learning. (Guru menggukan media elektronik berupa film atau lagu dalam pembelajaran.)

$\begin{array}{llll}1 & 2 & 3 & 4\end{array}$

11. The teacher always makes the class interactive and familiar atmosphere. (Guru selalu membuat kelas menjadi interaktif dan suasana akrab.)
1
2
3
4

12. The teacher provides examples, appropriate solutions, and appropriate feedback on students' questions. (Guru memberikan contoh dan memberikan solusi dan umpan balik yang tepat terhadap pertanyaan siswa.)
1
2
3
4

13. The teacher assigns tasks to students in creative and imaginative forms such as making dramas, poetry, etc. (Guru memberikan tugas kepada siswa dalam bentuk yang kreatif dan imajinatif seperti membuat drama, puisi dll.)
1
2
3
4

14. The teacher is fair in scoring and providing feedback on the students' work. (Guru adil dalam pemberian nilai dan memberikan umpan balik terhadap pekerjaan siswa.)
1
2
3
4

15. The teacher is well-dressed, and looks handsome/beautiful. (Guru berpenmpilan menarik seperti berpakaian rapih, tampan/cantik.)

$\begin{array}{llll}1 & 2 & 3 & 4\end{array}$


16. The teacher shows positive attitudes, wisdoms, funs and affections to students. (Guru mempunyai sikap, bijaksana, menyenangkan serta memperlihatkan kasih sayang kepada siswa.)
1
2
3
4

17. The teacher can control emotions at times that are not fun. (Guru dapat mengontorol emosi pada saat yang tidak menyenangkan.)
1
2
3
4

18. Teacher shows a cheerful attitude. (Guru menunjukkan sikap yang riang.)
1
2
3
4

19. The teacher exhibits an attitude that can be emulated by the students. (Guru memperlihatkan sikap yang dapat dicontoh oleh siswa/siswi.)
1
2
3
4

20. The teacher has high dedication. (Guru mempunyai dedikasi yang tinggi.)
1
2
3
4

21. The teacher teaches in a hurry. (Guru mengajar dengan terburu-buru.)
1
2
3
4

22. The teacher explains materials by reading the text-book. (Guru menjelaskan materi dengan membaca buku teks.)
1
2
3
4

23. The teacher has an inaccurate pronunciation. (Guru mempunyai pengucapan yang tidaktepat.)
1
2
3
4

24. The teacher uses the Indonesian language as the instructional language instead of the target language. (Guru menggunakan bahasa Indonesia pada saat pembelajaran.)

$$
\begin{array}{llll}
1 & 2 & 3 & 4
\end{array}
$$

25. The teacher cares on the students' mistakes, but he/she does not convey a clear and precise solution. (Guru peduli pada kesalahan siswa, tetapi tidak memberikan solusi yang jelas dan tepat.) 


$\begin{array}{llll}1 & 2 & 3 & 4\end{array}$

26. The teacher gives assignments without explaining the material. (Guru memberikan tugas tanpa menjelaskan materinya.)
1
2
3
4

27. The teacher smokes in the classroom. (Guru merokok di dalam kelas.)
1
2
3
4

28. The teacher keeps on sitting while explaining the subject matter in the classroom. (Guru duduk pada saat menjelaskan materi pelajaran di dalam kelas.)
1
2
3
4

29. The teacher only focuses on grammar. (Guru hanya fokus pada grammar.)
1
2
3
4

30. Teacher does not give sufficient subject matter explanation. (Guru menjelaskan materi pelajaran dengan tidak sempurna.)
1
2
3
4

31. The teacher imposes his/her wish on the students without considering the students' opinions. (Guru memaksakan keinginannya pada siswa tanpa mengetahui pendapat siswa.)
1
2
3
4

32. The teacher does not care about students. (Guru tidak peduli terhadap siswa.)

$\begin{array}{llll}1 & 2 & 3 & 4\end{array}$

33. The teacher never teaches in class. (Guru tidak pernah mengajar di dalam kelas.)
1
2
3
4

34. The teacher gives too many assignments and never discusses them. (Guru memberikan tugas terlalu banyak dan tidak pernah membahasnya.)
1
2
3
4

35. The teacher gets so angry if the student cannot do the task. (Guru sangat marah jika siswa tidak dapat mengerjakan tugas.) 

1
2
3
4

36. The teacher seldom explains the correct sentences. (Guru jarang menjelaskan tentang kalimat yang benar.)
1
2
3
4

37. The teacher always asks students to write without practicing other skills such as, speaking, listening. (Guru selalu meminta siswa menulis tanpa mempraktekkan keterampilan lain seperti, berbicara, mendengarkan.)
1
2
3
4

38. The teacher only focuses on smart students. (Guru hanya focus pada siswa yang pintar.)
1
2
3
4

39. The teacher left his students in class. (Guru meninggalkan siswanya dalam kelas.)
1
2
3
4

40. The teacher dresses poorly and badly. (Guru berbusana kurang sopan dan cara berpakaian berpakaiannya buruk.)
1
2
3
4

41. The teacher shows childish attitudes. (Guru bersikap kekanak-kanakan.)
1
2
3
4

42. The teacher gives negative labels to students like "stupid" or other labels. (Guru memberi label negatif pada siswa seperti "bodoh" atau sejenisnya.)
1
2
3
4

43. Teacher creates a tensed classroom atmosphere. (Guru membuat suasana kelas menegangkan.)
1
2
3
4

44. The teacher does not care whether students pay attention or not during explaining the material, and makes the students sleepy. (Guru tidak peduli apakah siswa memperhatikan atau tidak pada saat menjelaskan dan membuat siswa mengantuk.)

$\begin{array}{llll}1 & 2 & 3 & 4\end{array}$ 


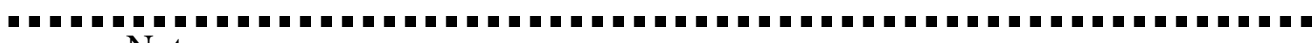

Notes:

\section{Scoring Information}

- The questionnaires consist of 20 Positive Statements (PS) numbers 1-20; and 24 Negative Statements (NS) numbers 21-44.

- For PS, the scores $1=1 ; 2=2 ; 3=3$; and $4=4$. The score obtained by the teacher from PS ranges from 20 to 80 .

- $\quad$ For NS, the scores $1=4 ; 2=3 ; 3=2$; and $4=1$. Teacher scores range from 24 to 96

- $\quad$ Both scores will be summed, and will range from 44-176.

- The sum is divided by 2 to obtain the final score.

- $\quad$ The final score will range from 22 to 88 .

- Example: Teacher A gets scores PS 60 and NS 70. The final score is $60+70$ $=130 / 2=65$ (effective)

- The score is categorized as follows:

- $72-88=$ very effective

- $55-71=$ effective

- $\quad 38-54=$ ineffective

- $\quad 22-37$ = very ineffective 